Newfoundland and Labrador Studies

\title{
Larry Matthews. An Exile's Perfect Letter
}

\section{Johnathan H. Pope}

Volume 35, Number 1-2, 2020

URI: https://id.erudit.org/iderudit/1076776ar

DOI: https://doi.org/10.7202/1076776ar

See table of contents

Publisher(s)

Faculty of Arts, Memorial University

ISSN

1719-1726 (print)

1715-1430 (digital)

Explore this journal

Cite this review

Pope, J. (2020). Review of [Larry Matthews. An Exile’s Perfect Letter].

Newfoundland and Labrador Studies, 35(1-2), 159-161.

https://doi.org/10.7202/1076776ar viewed online.

https://apropos.erudit.org/en/users/policy-on-use/ 
Larry Matthews. An Exile's Perfect Letter. St. John's: Breakwater Books, 2018. ISBN 978-1-550-81707-2

In his follow-up to The Artificial Newfoundlander (2010), Larry Matthews breathes new life into protagonist Hugh Norman, the 62-year-old Memorial University English professor whose inner monologue forms the narrative core of An Exile's Perfect Letter. While the novel frequently traverses the streets and haunts of St. John's and its environs (along with a brief detour to St. Pierre), its true setting is the inside of Hugh's head. The novel's primary narrative and thematic thrust revolves around the struggle to find meaning amid random but temptingly - yet improbably — connected events and coincidences. The sudden, largely unexpected death of Hugh's childhood friend encourages our narrator to take stock of his own life during the dusk of his career as a literary critic. News of a missing person in St. Pierre and, later, Hugh's discovery of an actual dead body while on a walk serve to galvanize his preoccupation with mortality and the meaning - or lack thereof - of life. Is the universe trying to send him a message? Or is he simply imposing a false narrative of cosmic significance onto these events, despite his best effort to avoid doing just that? Hugh is persistently caught between a desire for greater meaning and his rational disinclination to embrace it.

Hugh's accomplishments and legacy as a professor persist as an ambiguous source of anxiety throughout the narrative. After many years of teaching and research, Hugh has been rewarded with tangible proof of his success, namely those former students - writers, filmmakers - who credit him as an influence and of whom he is proud. However, Hugh has also inspired less laudable students such as his ex-son-in-law, the philandering Foley, who briefly becomes Hugh's temporary roommate while his wife, Maureen, is out of town on a writer's retreat. Foley, an aspiring freelance writer, has been commissioned to contribute to an anthology on "Men's accounts of the birth of their children" (100). In one of the most genuinely funny passages of the novel, Foley authors a self-indulgent and entirely unself-conscious 
pseudo-Marxist account of the birth of his son set against the backdrop of the 1995 Oklahoma City bombing. Hugh's view of the St. John's and Canadian arts community is one that expresses an anxious, perhaps ambivalent, perspective, as truly moving and subtle theatre cohabits with self-serious artists depicting icebergs having sex. In a similar vein, some of Hugh's traditionalist colleagues in the university - who try to recruit him to their cause - feel threatened and incensed by junior members of faculty advocating the study of post scripts and video games, replacing literature with popular culture. "Imagine having to pretend to believe in the importance of this crap, or (worse) actually to believe in it," he laments (144). At the same time, Hugh is self-aware enough to admit that his own critical work will likely go unread by all but a tiny group of like-minded specialists.

Ultimately, the narrator's contemplation of mortality and the struggle to find meaning is mirrored by the novel's contemplation of the state of Canadian literature and of literary criticism. In this regard, An Exile's Perfect Letter serves as both - or vacillates between - a eulogy and a graduation speech. There is hope for what is possible but also a parental concern that in pursuing that potential, the new generation might forget their roots. But Matthews's wry prose and satiric tone also hint, tongue in cheek, that we might just be toasting a corpse. For readers well versed in Canadian literature, one of the deep pleasures of the novel is its metatextuality as Matthews writes about writing through copious allusions to other writers. Hugh's own observations about the world around him are frequently filtered through the poems and novels that have defined his career. While such an approach can quickly become tedious or excessively novel in other writers, Matthews finds an effective balance that serves to reinforce the core themes of his novel.

An Exile's Perfect Letter is undoubtedly a witty and humorous novel, but its success is not grounded in how often or how hard Matthews can make the reader laugh. Certainly, not all readers will find Hugh's brand of "honest masculinity" to their tastes. Rather, the novel succeeds in using this humour to ask probing questions about how a life is 
measured according to the shifting metrics of family, friends, career, culture, and aesthetics. Akin to Hugh's allusive and intertextual interpretation of the world around him, reading Matthews's novel put me in mind of Anton Chekhov's dramatic examination of similar themes, although handled in a very different manner and context. An Exile's Perfect Letter is a worthwhile read in good spiritual company.

Johnathan H. Pope

Grenfell Campus, Memorial University 